\title{
NIEWYKORZYSTANA SZANSA? O INKLUZYWNYM POTENCJALE NIEMIECKIEJ KONCEPCJI DUSZPASTERSTWA SZKOLNEGO JAKO ŹRÓDLE INSPIRACJI DLA KOŚCIOŁA W POLSCE
}

DOI: http://dx.doi.org/10.12775/TiCz.2021.008

Streszczenie. Młodzi ludzie postrzegają Kościół katolicki w Polsce jako instytucję zamkniętą na osoby o innym światopoglądzie oraz niezdolną do podejmowania otwartego dialogu w obliczu przemian społeczno-kulturowych. Przezwyciężeniu dyskrepancji, dostrzeganych przez młodzież w działalności Kościoła, ale także napięć zachodzących pomiędzy inkluzją a ekskluzją w podejściu do religii w ramach procesów wychowania, edukacji i socjalizacji, mogłoby pomóc duszpasterstwo szkolne. Jest ono jednym z zapomnianych zasobów, ale też w polskiej koncepcji edukacji religijnej ciągle niewykorzystaną szansą. Celem niniejszego artykułu jest w tym kontekście poszukiwanie inspiracji dla Kościoła w Polsce w praktyce duszpasterstwa szkolnego w Niemczech, rozumianego jako pozalekcyjna i całkowicie dobrowolna oferta pastoralna, będąca płaszczyzną szeroko rozumianej inkluzji, stawiającej w centrum swoich działań konkretną osobę - ucznia, rodzica lub nauczyciela - z całym jej bagażem doświadczeń o charakterze indywidualnym lub społecznym.

Słowa kluczowe: inkluzja; duszpasterstwo szkolne; edukacja religijna.

Abstract. Missed chance? About the inclusive potential of the German concept of school pastoral care as a source of inspiration for the Church in Poland. Young people perceive the Catholic Church in Poland as an institution closed to people with 
a different worldview and unable to engage in open dialogue in the face of socio-cultural changes. The school pastoral care, which is one of the forgotten resources in the Polish concept of religious education, could help overcome the discrepancy in the activity of the Church perceived by young people, as well as the tensions between inclusion and exclusion in the approach to religion as part of the processes of upbringing, education and socialization. In this context, the aim of this article is to look for inspiration for the Church in Poland in the practice of school pastoral care in Germany understood as an extracurricular and completely voluntary pastoral offer, which is a plane of broadly understood inclusion, which places a specific person - a student, parent or teacher - at the center of its activities with all her baggage of individual or social experiences.

Keywords: inclusion; school pastoral care; religious education.

\section{WPROWADZENIE}

Raport pt. Kościót w Polsce, opublikowany przez Katolicką Agencję Informacyjną, nie pozostawia żadnych złudzeń, że młodzi ludzie podlegają coraz to intensywniejszym procesom sekularyzacji1. Godna uwagi jest jedna $\mathrm{z}$ cytowanych $\mathrm{w}$ opracowaniu odpowiedzi na pytanie, co czuje młodzież, gdy słyszy słowo „Kościół”: „Odczuwam rozgraniczenie między Kościołem, którego osobiście doświadczam i Kościołem instytucjonalnym. Przeszkadza mi zamknięcie na inność, nieumiejętność podejmowania dialogu"2.

„Przyspieszona sekularyzacja”" ${ }^{\text {w }}$ Polsce wydaje się czerpać swoje siły także z faktu, że wśród wielu polskich katolików coraz częściej pojawiają się postawy na wskroś przepełnione uprzedzeniami, a nawet niechęcią i lękiem wobec osób o innym kolorze skóry, wyznawanej religii, światopoglądzie czy orientacji seksualnej ${ }^{4}$. Czymś koniecznym jest

${ }^{1}$ Por. A. Rasińska, Młodzi w Kościele, w: Kościół w Polsce. Raport, red. Katolicka Agencja Informacyjna, Warszawa 2021, s. 119-130.

2 Tamże, s. 122.

3 J. Mariański, Katolicyzm polski w procesie przemian, „Władza Sądzenia” 6 (2015), s. 30.

${ }^{4}$ Zob. m.in.: Pew Research Center, Eastern and Western Europeans Differ on Importance of Religion, Views of Minorities and Key Social Issues, https://www.pewforum.org/wp-content/uploads/sites/7/2018/10/Eastern-Western-Europe-FOR-WEB-1. pdf (dostęp: 10.01.2021); B. Pasamonik, Moral panic about refugees in Poland as a mani- 
zatem nie tylko poszerzenie horyzontów wychowawczo-duszpasterskich w naszym kraju, ale także zabiegnie o nowe (również pozalekcyjne) formy kształcenia religijnego, wyposażające uczniów i uczennice w wiedzę i kompetencje związane z postrzeganiem własnego punktu widzenia Boga, człowieka i świata jako jednej z wielu możliwych opcji ${ }^{5}$.

Przezwyciężeniu dyskrepancji, dostrzeganych przez młodzież w działalności Kościoła, ale także napięć zachodzących pomiędzy inkluzją a ekskluzją w podejściu do religii w ramach procesów wychowania, edukacji i socjalizacjí, mogłoby pomóc duszpasterstwo szkolne, które jest jednym z zapomnianych zasobów (a może i niewykorzystaną szansą) w polskiej koncepcji edukacji religijnej ${ }^{7}$. Celem niniejszego artykułu, we wspomnianym kontekście poznawczo-naukowym, jest prezentacja duszpasterstwa szkolnego w Niemczech jako oferty pozalekcyjnej i całkowicie dobrowolnej, będącej płaszczyzną szeroko rozumianej inkluzji, stawiającej w centrum swoich działań pastoralno-pedagogicznych konkretną osobę: ucznia, rodzica lub nauczyciela, z całym bagażem jej doświadczeń o charakterze indywidualnym lub społecznym.

Już na wstępie należy zauważyć, że intencją niniejszego artykułu nie jest proste przełożenie doświadczeń niemieckich w odmienny, polski kontekst kulturowo-społeczny, lecz poszukiwanie ubogacających inspiracji, które mogą zrodzić nowe impulsy do odważniejszego zaangażowania Kościoła na rzecz polskiej szkoły. Jakakolwiek próba adaptacji duszpasterstwa szkolnego w polskich warunkach musiałby zostać poprzedzona pogłębioną, krytyczną analizą, uwzględniającą mocne i słabe strony praktyki pedagogiczno-duszpasterskiej Kościoła nie tylko w Polsce, lecz

festation of cultural transformation. „Multicultural studies” 1 (2017), s. 87-101; A. Piela, A. Łukjanowicz, Islamophobia in Poland. National Report 2017, http://www.islamophobiaeurope.com/wp-content/uploads/2018/04/Poland.pdf (dostęp:14.02.2021); P. Żuk, P. Żuk, "Murderers of the unborn" and "sexual degenerates": analysis of the "anti-gender" discourse of the Catholic Church and the nationalist right in Poland, "Critical Discourse Studies" 17 (2020) 5, s. 566-588.

5 Por. M. Humeniuk, I. Paszenda, Od redaktorek, w: Między ekskluzją a inkluzja w edukacji religijnej, red. M. Humeniuk, I. Paszenda, Wrocław 2017, s. 11.

${ }^{6}$ Por. tamże.

7 Zob. M. Chrostowski, Edukacja religijna w Polsce: czas na zamianę?, „Łódzkie Studia Teologiczne" 29 (2020) 3, s. 39-52. 
także w Niemczech, przy jednoczesnym koncepcyjnym zakorzenieniu takiego modelu w rzeczywistych uwarunkowaniach funkcjonowania szkoły i Kościoła w Polsce. Poza tym czymś koniecznym byłoby także uwzględnienie olbrzymiego dorobku polskiej myśli religijno-pedagogicznej i teologicznej ${ }^{8}$.

\section{ZARYS KONCEPCYJNY DUSZPASTERSTWA SZKOLNEGO}

Duszpasterstwo szkolne, na gruncie polskiej myśli religijno-pedagogicznej lub pastoralnej, nie jest pojęciem obcym ${ }^{9}$. Należy jednak zaznaczyć, że Kościół w Polsce nie opracował dotychczas żadnej całościowej koncepcji tego zagadnienia i związanej z nim działalności ${ }^{10}$. Źródło inspiracji może stanowić w tym zakresie praktyka pastoralna Kościoła katolickiego w Niemczech, gdzie duszpasterstwo szkolne rozumiane jest jako posługa i zaangażowanie chrześcijan na rzecz humanizacji środowiska szkolnego ${ }^{11}$. Nie jest to jednak posługa o stałym i niezmiennym charakterze, lecz realna rzeczywistość, która ciągle się rozwija i musi nabierać

${ }^{8}$ Próby wypracowania całościowej, praktycznej, sytuacyjnej i zorientowanej na przyszłość koncepcji duszpasterstwa szkolnego w Polsce, na przykładzie uwarunkowań w diecezji łomżyńskiej, podejmuje się M. Chrostowski, który w swojej książce poszukuje inspiracji dla takiej działalności w ramach krytycznej analizy sprawdzonych modeli szkolno-pastoralnych w Niemczech, zob.: M. Chrostowski, Schulpastoral für alle! Religionspädagogische und pastorale Impulse deutscher Schulpastoral für ein schulpastorales Modell in Polen (am Beispiel der Diözese Łomża), Berlin 2021 (w druku).

${ }^{9}$ Zob. m.in.: M. Chrostowski, Edukacja religijna; M. Polak, Pastoralna posługa Kościoła w szkole. Inspiracje dla polskiego duszpasterstwa, „Studia Pastoralne” 3 (2007), s. 275-293; A. Zuk, Pastoralne zaangażowanie parafii w struktury szkolne: innowacyjny model wychowania społeczno-kulturowego, w: Człowiek - Środowisko życia - Edukacja, red. W. Theiss, Toruń 2012, s. 228-262; R. Czekalski, Duszpasterstwo szkolne - czy wykorzystana szansa?, „Ateneum Kaplanskie” 3 (2004), s. 514-528; R. Chałupniak, Lekcja religii a duszpasterstwo szkolne na przykładzie Kościoła w Niemczech, https://www. katecheta.pl/Archiwum/2008/Katecheta-9-2008 (dostęp: 28.05.2021).

10 Por. M. Chrostowski, Edukacja religijna, s. 44.

11 Por. Sekretariat der Deutschen Bischofskonferenz, Im Dialog mit den Menschen in der Schule. Eckpunkte zur Weiterentwicklung der Schulpastoral, Bonn 2020, s. 5; Sekretariat der Deutschen Bischofskonferenz, Schulpastoral - der Dienst der Kirche an den Menschen im Handlungsfeld Schule, Bonn 1996, s. 7. 
nowego kształtu w nawiązaniu do wyzwań codzienności ${ }^{12}$. Tak rozumiane zaangażowanie chrześcijan w szkołach wykracza daleko poza granice edukacji religijnej. Jest realizowane przede wszystkim jako towarzyszenie i poradnictwo, realna pomoc w kształtowaniu przyjaznego uczniom środowiska szkolnego, współpracy na rzecz tworzenia siatki powiązań pomiędzy szkołą a instytucjami kościelnymi i świeckimi. Rozumiana jest także jako oferta zajęć rekreacyjnych i przedsięwzięcie wspierające rozwój człowieka w sensie duchowym i intelektualnym ${ }^{13}$.

W interpretacji duszpasterstwa szkolnego przez biskupów niemieckich nadrzędną rolę odgrywa termin "humanizacja” (łac. humanus - ludzki; czynić coś bardziej ludzkim, humanitarnym ${ }^{14}$ ), określający główny cel zaangażowania Kościoła w szkołach. Stosunkowo wysoki stopień abstrakcji tego słowa sprawia, że pod terminem „duszpasterstwo szkolne” kryje się olbrzymia paleta różnorodnych aktywności pastoralno-psychologiczno-pedagogicznych ${ }^{15}$. Taki dobór słów, dokonany przez niemieckich biskupów sugeruje, że teologiczne korzenie duszpasterstwa szkolnego sięgają konstytucji duszpasterskiej Gaudium et spes, w której ojcowie soborowi zauważają, że

w całym świecie coraz bardziej rośnie poczucie autonomii i zarazem odpowiedzialności, co ma ogromne znaczenie dla duchowej i moralnej dojrzałości rodzaju ludzkiego. Bardziej klarowne okaże się to wtedy, kiedy uświadomimy sobie fakt jednoczenia się świata oraz zadanie, stojące przed nami, by w prawdzie i sprawiedliwości budować lepszą rzeczywistość. W ten sposób jesteśmy świadkami narodzin nowego humanizmu,

12 Por. tamże.

${ }_{13}$ Por. M. Seibt, Schulpastoral an berufsbildenden Schulen des dualen Schulsystems: eine qualitativ-empirische Untersuchung zur Entwicklung von Qualitätskriterien für eine gelingende Schulpastoral an Berufsschulen, Berlin 2008, s. 25; H. Demmelhuber, Schulpastoral in der Diözese Rottenburg-Stuttgart: Ein Dienst an und mit den Menschen im Lebensfeld Schule, w: Huch, was machen die denn da! Projekt Schulpastoral an Hauptschulen und Beruflichen Schulen 2000/2003, Dokumentation und Ergebnisse, red. Referat Schulpastoral Diözese Rottenburg-Stuttgart, Rottenburg-Stuttgart 2004, s. 6.

${ }_{14}$ Por. http://www.edupedia.pl/words/index/show/285272_slownik_wyrazow_obcych-humanizowac.html (dostęp: 06.02.2021).

${ }^{15}$ Por. U. Kumher, Schulpastoral und religiöse Pluralität. Ein Konzeptentwurf für die Auseinandersetzung mit religiöser Pluralität, Würzburg 2008, s. 29 n. 
gdzie człowieka określa przede wszystkim odpowiedzialność wobec jego współbraci i wobec historii ${ }^{16}$.

W tym miejscu należy zauważyć, że jest to wyraźne odniesienie do zwięzłej formuły francuskiego teologa Henri de Lubaca (1896-1991), który, odwołując się do dialogu Kościoła $\mathrm{z}$ ateizmem czy też wspólnoty wierzących z dzisiejszym światem, zauważa, że zawsze należy dokonać wyboru pomiędzy „humanizmem z Bogiem” lub „humanizmem bez Boga"17. Zaprezentowany tu egzystencjalny wybór wyznacza także ramy duszpasterstwa szkolnego, które powinno pomagać wszystkim uczestnikom środowiska szkolnego (uczniom, rodzicom, nauczycielom, pracownikom technicznym) w doświadczaniu wsparcia płynącego z wiary, zaakceptowaniu wartości chrześcijańskich oraz kształtowaniu swojego życia w chrześcijańskim duchu ${ }^{18}$.

Tak rozumiana działalność Kościoła na rzecz całej szkoły i wszystkich tworzących ją osób ${ }^{19}$ musi być prowadzona na podstawie określonych pryncypiów, które nie pozwolą na zmianę lub zatracenie jej pierwotnego i otwartego na wszystkie osoby charakteru ${ }^{20}$. Pryncypia te są zarazem swoistymi kryteriami jakości duszpasterstwa szkolnego. Ich kanon tworzą m.in. następujące elementy ${ }^{21}$ :

a) punktualność sytuacyjna - za niezwykle ważną należy uznać punktualność inicjatyw i projektów duszpasterskich (a nie ich

${ }^{16}$ Sobór Watykański II, Konstytucji duszpasterska o Kościele w świecie współczesnym „Gaudium et spes”, 7. Grudnia 1965, Wrocław 2016, nr 55.

17 Zob. H. de Lubac, Die Tragödie des Humanismus ohne Gott. Feuerbach - Nietzsche - Comte und Dostojewskij als Prophet, Salzburg 1950.

${ }_{18}$ Por. S. Schmitz, Schulpastoral kontrovers, Ein kritischer Blick auf ungeklärte Verhältnisse zwischen Religionsunterricht, Schulseelsorge und Gemeindepastoral, Münster 2006, s. 102 n.

${ }_{19}$ Por. K. Roth, Sinnhorizonte christlich gestalteter Schule. Eine schulpädagogische Begründung der Schulpastoral an staatlichen Schulen, Hamburg 2013, s. 123.

${ }^{20}$ Por. H. Mendl, Schulpastoral. Schulpädagogische, theologische und religionspädagogische Rahmendaten, w: Schulpastoral konkret. Eine jugendverbandliche Perspektive, red. J. Martina, J. Kittel, Düsseldorf 2004, s. 27.

${ }^{21}$ Zob. H. Mendl, Ch. Schwarz, Schulgottesdienst - Fakten, Einschätzungen, Perspektiven, „Kontakt. Informationen zum Religionsunterricht im Bistum Augsburg“ 1 (2000), s. 35-38. 
częstotliwość) w odniesieniu do bieżących sytuacji w szkole. Decyzje, dotyczące kształtu i treści ofert duszpasterskich, powinny być podejmowane na płaszczyźnie szeroko rozumianej współpracy międzyosobowej i instytucjonalnej tak ${ }^{22}$, aby odnosiły się do tradycji szkolnych, potrzeb wszystkich osób zaangażowanych w środowisko szkolne i do całego programu nauczania ${ }^{23}$;

b) kapitał ludzki - najcenniejszym elementem zasobów duszpasterstwa szkolnego jest człowiek; jego chrześcijańskie zaangażowanie należy postrzegać jako podstawową wartość i życiodajne źródło każdej akcji duszpasterskiej w środowisku szkolnym ${ }^{24}$. Zespół osób zaangażowanych w duszpasterstwo szkolne obejmuje wszystkich, którzy chcą pracować w jego ramach (tj.: uczniów, ich rodziców, wychowawców, nauczycieli różnych przedmiotów, wolontariuszy, instytucje kościelne i stowarzyszenia młodzieżowe, a także personel techniczny) i dzielić się z innymi własnymi doświadczeniami, aby wspólnie uczynić szkołę miejscem bardziej przyjaznym ludziom ${ }^{25}$. W takim ujęciu duszpasterstwo szkolne zawsze koncentruje się na ludziach z ich zainteresowaniami, możliwościami, potrzebami i historiami $\dot{z} y$ cia $^{26}$;

c) gościnność - w programie duszpasterstwa szkolnego z założenia może uczestniczyć każdy, o ile wyrazi taką wolę. Zaproszenie kieruje się do wszystkich, niezależnie od religii, wieku, płci, pochodzenia, roli, klasy społecznej, stanu cywilnego, orientacji

${ }^{22}$ Por. H. Mendl, dz. cyt., s. 28.

${ }^{23}$ Por. M. Kienst, Schulpastoral in der Erzdiözese Freiburg - Übersicht zu den Praxisfeldern, w: Schulkultur mitgestalten. Pastorale Anregungen und Modelle, red. J. Burkhard, P. Wehrle, Freiburg 2005, s. 39 (35-38).

${ }^{24}$ Por. Katholisches Schulkommissariat in Bayern, RU-aktuell. Schulpastoral an Hauptschulen. Dokumentation und Ergebnisse des Erprobungsversuchs 1998/99-2001, München 2001, s. 14.

25 Por. M. Seibt, Schulpastoral an berufsbildenden Schulen des dualen Schulsystems: eine qualitativ-empirische Untersuchung zur Entwicklung von Qualitätskriterien für eine gelingende Schulpastoral an Berufsschulen, Berlin 2008, s. 33.

${ }^{26}$ Por. G. Lames, Schulseelsorge als soziales System. Ein Beitrag zur ihrer praktischtheologischen Grundlegung, Stuttgart-Berlin-Köln 2000, s. 31. 
seksualnej itp. ${ }^{27}$ Gościnność, a tym samym otwartość na wszystkich, daje każdemu możliwość współuczestniczenia i doświadczenia, jak w praktyce kształtuje się szkolna oferta duszpasterska. Jednocześnie uczestnictwo nie jest dla tych osób wiążące ani obowiązkowe. Zasada gościnności jest czymś niezwykle ważnym, zwłaszcza w dużych miastach ${ }^{28}$ (ze względu na ich wielokulturowość, pochodzenie etniczne czy wyznawaną religię), ponieważ umożliwia spotkanie i dialog między ludźmi o różnych poglądach i wizjach świata ${ }^{29}$;

d) ekumenizm/dialog międzyreligijny ${ }^{30}$ - wyznawcy różnych religii lub odmiennych wyznań uczęszczają do tych samych szkół ${ }^{31}$. W duszpasterstwie szkolnym, w jego ekumenicznej/międzyreligijnej orientacji, ważne jest, aby od samego początku pomagać uczniom w rozwoju dojrzałej i świadomej przynależności do własnej wspólnoty religijnej ${ }^{32}$. Jednak oferta duszpasterstwa szkolnego winna również wykraczać poza granice religii i wyznań, aby w środowisku szkolnym wzbudzić i wzmocnić szacunek i gotowość do współpracy międzywyznaniowej i mię-

27 Por. H. Mendl, dz. cyt., s. 29.

${ }^{28}$ W dużych miastach takich, jak m.in. Warszawa lub Wrocław do szkół uczęszczają dzieci i młodzież reprezentująca praktycznie wszystkie kręgi cywilizacyjne, zob. K. Błeszyńska, Dzieci obcokrajowców w polskich placówkach oświatowych - perspektywa szkoły. Raport z badań. Warszawa 2010.

${ }^{29}$ K. Roth, Sinnhorizonte christlich gestalteter Schule, s. 135.

${ }^{30}$ Choć polscy katolicy stanowią zdecydowaną większość na etniczno-religijnej mapie Polski - 87,6\% ogółu ludności, to jednak nie mają oni w tym zakresie monopolu. Autorzy raportu Głównego Urzędu Statystycznego dotyczącego wyznań podkreślają, że w 2018 roku istniało w Polsce 186 różnych grup wyznaniowych, m.in.: buddyści, muzułmanie, żydzi, wyznawcy prawosławia, luteranie, grekokatolicy, Świadkowie Jehowy, wyznawcy Starokatolickiego Kościoła Mariawitów oraz członkowie ponad 150 innych kościołów, wyznań i ruchów religijnych, zob.: Główny Urząd Statystyczny, Wyznania religijne $w$ Polsce $w$ latach 2015-2018, https://stat.gov.pl/obszary-tematyczne/inne-opracowania/ wyznania-religijne/wyznania-religijne-w-polsce-20152018,5,2.html (dostęp: 29.05.2021).

${ }^{31}$ Por. H. Mendl, Religionsdidaktik kompakt. Für Studium, Prüfung und Beruf, München 2011, s. 236.

32 Por. P. Görtz, Ignatianische Schulpastoral. Anregungen für eine spirituelle Praxis an konfessionellen Schulen, Würzburg 2014, s. 125. 
dzyreligijnej ${ }^{33}$. Szkoła umożliwia przeżywanie żywego ekumenizmu poprzez organizację wspólnych przedsięwzięć, np.: dnia modlitwy o pokój na świecie, ekumenicznych obchodów początku i końca roku szkolnego, ale także wspólnych gier czy akcji rękodzielniczych ${ }^{34}$;

e) dobrowolność - podstawą duszpasterstwa szkolnego jest jego zapraszający charakter, wyrażający się przede wszystkim w ofertach zajęć pozalekcyjnych i pozaszkolnych ${ }^{35}$. Udział w duszpasterstwie szkolnym powinien być całkowicie dobrowolny, ponieważ obejmuje poszukiwanie odpowiedzi na pytania o naturę wiary i sensu życia ${ }^{36}$. W tym sensie duszpasterstwo szkolne nie powinno nigdy pełnić funkcji moralizatorskiej ani narzucać żadnych zasad postępowania, lecz pozostawić je dobrowolnej i niczym nieprzymuszonej decyzji danej osoby ${ }^{37}$.

Każde z powyższych pryncypiów akcentuje inkluzywny potencjał duszpasterstwa szkolnego, ponieważ do udziału w jego ofercie zapraszani są wszyscy, a zwłaszcza ci, którzy zwykle są wykluczeni, napiętnowani i dyskryminowani. Duszpasterstwo szkolne staje się więc atrakcyjną ofertą dla pokrzywdzonych i ubogich. Nabiera także wymiaru politycznego poprzez przezwyciężanie wykluczenia i szeroko rozumianą inkluzję ${ }^{38}$.

\section{RELACJE POMIĘDZY INKLUZJĄ A DUSZPASTERSTWEM SZKOLNYM}

W odniesieniu do edukacji i środowiska szkolnego inkluzja skupia się na zbliżaniu, współpracy, akceptacji, tolerancji, wzajemnym wsparciu i pogłębianiu interakcji społecznych. Nie chodzi tu tylko o transfer wiedzy, ale także o kształtowanie pozytywnych postaw i socjalizację osób

${ }^{33}$ Por. H. Mendl, dz. cyt., s. 29.

${ }^{34}$ Por. K. Roth, Sinnhorizonte christlich gestalteter Schule, s. 133.

35 Por. Erzdiözese Freiburg, Verbindlicher Rahmen für die Schulpastoral in der Erzdiözese Freiburg, Freiburg i. Br. 2006, s. 11.

${ }^{36}$ Por. H. Mendl, dz. cyt., s. 30.

37 Por. M. Seibt, dz. cyt., s. 33; por. także: P. Görtz, dz. cyt., s. 123.

${ }^{38}$ Por. P. Görtz, dz. cyt., s. 123. 
ze zróżnicowanymi potrzebami ${ }^{39}$. Inkluzja w węższym zakresie oznacza włączenie dzieci i młodzieży ze specjalnymi potrzebami edukacyjnymi do szkół ogólnokształcących i zawodowych. W szerszym ujęciu opisuje nurt pedagogiki szkolnej ${ }^{40}$, która postrzega szkołę jako miejsce wspierające i wspomagające nie tylko naukę, lecz także kształtujące przez uczniów (a także i nauczycieli) ich własnego życia ${ }^{41}$.

Należy pamiętać, że istotną rolę odgrywa w tym względzie klimat panujący w szkole. Wyraża się on przede wszystkim w subiektywnych odczuciach uczniów, związanych z ich pobytem w szkole. Uczniowie, których podstawowe potrzeby psychologiczne zostały zaspokojone podczas pobytu w szkole (np. poczucie przynależności do grupy, potrzeba autonomii i prawa do podejmowania decyzji, potrzeba bezpieczeństwa emocjonalnego i fizycznego), często określają tę instytucję jako dobrą i przypisują jej przyjazną atmosferę ${ }^{42}$.

Duszpasterstwo szkolne, rozumiane jako służba Kościoła na rzecz osób w środowisku szkolnym, postrzega siebie również jako swoistą siłę napędową rozwoju szkoły i staje przed wyzwaniami inkluzji ${ }^{43}$. Co więcej, inkluzja może być rozumiana jako podstawowy i wiodący nośnik

${ }^{39}$ Por. B. Skałbania, M. Babiarz, Edukacja włączająca jako przestrzeń dla rozwoju czy ryzyko wykluczenia i marginalizacji ucznia?, „Student Niepełnosprawny” 11 (2018), s. 19.

${ }^{40}$ W tym kontekście warto podkreślić, że na gruncie polskiej literatury pedagogicznej znane jest pojęcie pedagogiki integracyjnej, które należy traktować „jako pedagogiczny, naukowy namysł nad praktyką edukacji włączającej, a więc nad wychowaniem i kształceniem integracyjnym. Dlatego też [...] pedagogika integracyjna dotyczy nie tylko osób z różnego rodzaju niepełnosprawnością i specjalnymi potrzebami edukacyjnymi, ale także wszystkich tych, którzy dotknięci są tzw. wykluczeniem społecznym”, M. Sztaba, Pedagogika integracyjna wobec wieloaspektowego problemu samotności człowieka, „Rozprawy Społeczne" 8 (2013) 1, s. 52.

${ }^{41}$ Por. Sekretariat der Deutschen Bischofskonferenz, Im Dialog mit den Menschen in der Schule. Eckpunkte zur Weiterentwicklung der Schulpastoral, s. 12.

${ }^{42}$ Por. J. Surzykiewicz, Klimat a społeczna skuteczność szkoły, „Edukacja zdrowotna i promocja zdrowia w szkole” 12 (2007), s. 7; E. Jówko, Klimat społeczny w szkole inkluzyjnej, „Student Niepełnosprawny” 1 (2013), s. 46.

${ }^{43}$ Por. K. Roth, Inklusive Schulpastoral oder: was sich auch hinter dem schulpastoralen Prinzip der Gastfreundschaft verbergen kann, w: Handbuch Schulpastoral: für Studium und Praxis, red. A. Kaupp, G. Bussmann, B. Lob, B. Thalheimer, Freiburg 2015, s. 123. 
duszpasterstwa szkolnego, ponieważ posiada wspólny cel, którym jest: "pomagać ludziom żyć"44.

Trzeba jednak pamiętać, że nawet najbardziej szlachetne starania i zabieganie o tolerancyjną wspólnotę lub praktykowanie szacunku w kontaktach z innymi, mogą osiągnąć swoje granice lub zostać storpedowane przez innych ${ }^{45}$. Wówczas właśnie przychodzi szkole z pomocą duszpasterstwo szkolne (czerpiące siłę i motywację do pracy z chrześcijańskiej wizji Boga, człowieka i świata) ${ }^{46}$. Ewangelie dają świadectwo tego, że ludzie, którzy są blisko Jezusa, otwierają swoje domy, zapraszają innych do stołu, poszerzają serca i w ten sposób pozwalają, by orędzie o królestwie Bożym dotarło do wszystkich obecnych (zob. np.: Łk 19,1-10). Takie podejście do drugiego człowieka umożliwia zmianę, nowy początek, a tym samym uzdrowienie wewnętrzne i zewnętrzne, indywidualne i wspólnotowe. Później, w pierwszych wiekach chrześcijaństwa, to właśnie otwartość na siebie nawzajem i wzajemne posiłki wszystkich ochrzczonych w Chrystusie, stały się centralnym punktem życia pierwszych wspólnot. Okazuje się, że różnice pomiędzy religijnym pochodzeniem, płcią czy klasą społeczną są przecież niwelowane przez to, co łączy ludzi, przede wszystkim przez jedność w Jezusie. Chrześcijańska motywacja duszpasterstwa szkolnego kwestionuje wykluczenie i łamie kulturowe, religijne i społeczne granice ${ }^{47}$.

Duszpasterstwo szkolne w Niemczech to działalność o charakterze pastoralnym, która charakteryzuje się przede wszystkim punktualnością sytuacyjną i gościnnością. Głównym zadaniem duszpasterzy szkolnych jest uważne przyglądanie się dobru jednostki bądź całej wspólnoty szkolnej, czego oś stanowi diagnoza rzeczywistych potrzeb w środowisku szkolnym. Inkluzywna szkoła nie jest rozumiana wyłącznie jako placówka, do której uczęszczają uczniowie z różnymi niepełnosprawnościami, lecz podejmowane wysiłki mają również na celu systematyczną pracę w ramach różnorodnych projektów na rzecz prewencji i zwalczania negatyw-

${ }^{44}$ Por. Erzbistum Hamburg, Positionspapier zur Verhältnisbestimmung von Katechese, Religionsunterricht und Schulpastoral in Hamburg. Empfehlungen zur Kooperation der katholischen Schulen und Pfarreien, Hamburg 2015, s. 6.

${ }^{45}$ Por. K. Roth, Inklusive Schulpastoral oder, s. 124.

46 Zob. Diözese Augsburg, Christ sein in der Schule. Schulpastoral in der Diözese Augsburg, Augsburg 2006, s. 2 nn.

${ }^{47}$ Por. K. Roth, Inklusive Schulpastoral oder, s. 125. 
nego, nacechowanego uprzedzaniami podejścia do osób o jakiekolwiek odmienności ${ }^{48}$.

\section{PRZYKŁADY PROJEKTÓW I FORMY DZIAŁALNOŚCl}

Papież Franciszek w Evagelii gaudium zauważa, że „z naszej wiary w Chrystusa, który stał się ubogim, będąc zawsze blisko ubogich i wykluczonych, wypływa troska o integralny rozwój najbardziej opuszczonych w społeczeństwie" ${ }^{39}$. Chociaż w środowisku szkolnym podejmuje się wiele prób inkluzji, wykluczenia można doświadczyć zarówno w szkole, jak i poza nią. Duszpasterstwo szkolne może pomóc zmniejszyć istniejące w tym zakresie deficyty poprzez realizację różnych ofert i projektów, np.: wspieranie uczniów, ich rodziców, nauczycieli, pracowników technicznych w trudnych sytuacjach życiowych, pomoc dydaktyczno-psychologiczna osobom z trudnościami językowymi czy też trudnościami w nauce. Poza szkołą możliwe jest natomiast propagowanie integracji i solidarności poprzez wdrażanie projektów społecznych (np. międzykulturowe gotowanie; wycieczki z pensjonariuszami domów pomocy społecznej) lub ekonomiczne (np. zbiórki na rzecz mniejszości religijnych bądź etnicznych). Jednak nadrzędnym celem w środowisku szkolnym jest stworzenie przestrzeni, w której członkowie różnych wspólnot religijnych lub osoby o różnych światopoglądach będą mogły się wspólnie nie tylko modlić (np. pokój ciszy lub kaplica międzyreligijna), lecz także prezentować swoją perspektywę przy jednoczesnym bezwarunkowym zrozumieniu i akceptacji ${ }^{50}$.

Duszpasterstwo szkolne, jak zauważa K. Roth, jest o tyle inkluzywne, o ile zwraca uwagę na następujące elementy, m.in..$^{51}$ :

- otwarcie na wszystkich ludzi, bez żadnych warunków wstępnych, a także sporządzanie wszelkich informacji, listów i pisemnych

48 Por. tamże, s. 128.

${ }^{49}$ Franciszek, „Evangelii Gaudium”: Adhortacja apostolska Evangelii gaudium o głoszeniu Ewangelii w dzisiejszym świecie, 24 listopada 2013, Kraków 2013, nr 186.

${ }^{50}$ Por. W. Verburg, A. Abdel-Rahman, Christliche Schulpastoral in Schulen mit religiös pluraler Schülerschaft, w: Handbuch Schulpastoral: für Studium und Praxis, red. A. Kaupp, G. Bussmann, B. Lob, B. Thalheimer, Freiburg 2015, s. 147 n.

${ }^{51}$ Por. K. Roth, Inklusive Schulpastoral oder, s. 131-132. 
zaproszeń prostym językiem lub, jeśli to konieczne, nawet w języku ojczystym przyszłych uczestników ${ }^{52}$;

- umożliwienie uczestnictwa w ofertach duszpasterstwa szkolnego również młodym ludziom $\mathrm{z}$ rodzin znajdujących się $\mathrm{w}$ trudnej sytuacji finansowej ${ }^{53}$;

- taki dobór pomieszczeń, aby były pozbawione barier zarówno dla osób z różnymi niepełnosprawnościami (np. poruszających się na wózku inwalidzkim, jak i dla osoby z aparatem słuchowym, która potrzebuje pętli indukcyjnej $)^{54}$;

- poważne traktowanie chorób i niepełnosprawności, a niezbędne zadania, takie jak np.: podawanie leków, pomoc pielęgniarska, specjalne posiłki, są wykonywane odpowiedzialnie ${ }^{55}$;

- wszyscy, którzy są zaangażowani w duszpasterstwo szkolne, mają świadomość swoich własnych ograniczeń; biorą pod uwagę np. to, że dzieci i młodzież po przejściu traumy wymagają szczególnej uwagi i ochrony, a jeśli to konieczne, włączają się w organizację pomocy specjalistycznej ${ }^{56}$;

- wzmacnianie mocnych stron uczestników oraz umacniania rozumienia słabych pozytywnych zasobów, z których może czerpać cała grupa, przy czym w sensie dachowym - należy wskazywać na integracyjny potencjał wiary np.: wszyscy jesteśmy dziećmi jednego Boga ${ }^{57}$;

- stymulowanie uczestników do radzenia sobie z ograniczeniami i niepełnosprawnością, bo to samo w sobie pobudza do refleksji, towarzyszących jej dyskusji i spotkań ${ }^{58}$;

- zainteresowanie światem dzieci, młodzieży i dorosłych, szczególnie jeśli jest całkowicie różny ze względu na tło migracyjne oraz

\footnotetext{
${ }^{52}$ Por. tamże, s. 131.

${ }^{53}$ Por. tamże.

${ }^{54}$ Por. tamże.

${ }_{55}$ Por. tamże.

56 Por. tamże.

57 Por. tamże.

58 Por. tamże.
} 
postrzeganie go jako elementu ubogacającego i poszerzającego horyzonty ${ }^{59}$.

\section{PODSUMOWANIE}

Inkluzywny potencjał duszpasterstwa szkolnego w polskiej myśli i praktyce religijno-pedagogicznej stanowi z jednej strony nowe wyzwanie. Z drugiej zaś pozwala całej działalności pastoralnej Kościoła (także na rzecz środowiska szkolnego) świadomie oprzeć się na jej podstawowym zadaniu, którym jest "pomaganie ludziom życ" ${ }^{\prime 60}$. Jednakże rozważania wyłącznie na płaszczyźnie teoretycznej i związane z tym analizowanie działalności Kościoła w Niemczech, to ciągle zbyt mało. W Polsce w obliczu odchodzenia młodzieży od Kościoła - czymś koniecznym jest wzmożona debata nie tylko nad kształtem edukacji religijnej, ale także nad poszukiwaniem nowych form dotarcia do młodych ludzi oraz ukazania wiary chrześcijańskiej jako elementu, który wyraźnie wzbogaca życie indywidualne i społeczne. Wydaje się, że rolę swoistego hamulca w tym zakresie przyjmuje sam Kościól, który jest w pewnym sensie niegotowy do odważnych i dogłębnych reform coraz bardziej niewydolnej koncepcji edukacji religijnej ${ }^{61}$.

Duszpasterstwo szkolne pozostaje w naszym kraju ciągle niewykorzystaną szansą. Wydaje się, że wysiłek związany z implementacją zbliżonej koncepcji - po uprzednim, wyraźnie pogłębionym i krytycznym dostosowaniu jej do polskich warunków kulturowo-społecznych - mógłby stać się katalizatorem zmiany myślenia o samym Kościele, związanej z utożsamianiem go przez młodzież ze wspomnianym już „zamknięciem na inność" oraz „nieumiejętnością podejmowania dialogu” ${ }^{62}$. Poza tym odpowiednio przygotowani zawodowo, metodycznie i dydaktycznie dusz-

59 Por. tamże, s. 132.

${ }^{60}$ Por. Erzbistum Hamburg, dz. cyt., s. 6.

${ }^{61} \mathrm{O}$ niewydolności istniejącej koncepcji edukacji religijnej najlepiej świadczą dane statystyczne, które potwierdzają spadek liczby osób biorących udział w lekcjach religii: z 93\% w 2010 r. do 70\% w 2018 r. wśród uczniów ostatnich klas szkół ponadgimnazjalnych; por. M. Chrostowski, Edukacja religijna, s. 39.

${ }^{62}$ Por. A. Rasińska, dz. cyt., s. 122. 
pasterze szkolni z samego już założenia realizowaliby inkluzywny model edukacji i nieustannie poszukiwaliby dróg porozumienia i integracji na płaszczyźnie kontaktów z organami odpowiedzialnymi za oświatę, ale też z samymi szkołami, przedstawicielami innych wyznań i religii, a także różnymi instytucji pragnącymi czynnie wspierać inkluzję społeczną.

\section{BIBLIOGRAFIA}

Błeszyńska K., Dzieci obcokrajowców w polskich placówkach oświatowych - perspektywa szkoły. Raport z badań, Warszawa 2010.

Chałupniak R., Lekcja religii a duszpasterstwo szkolne na przykładzie Kościoła w Niemczech, https://www.katecheta.pl/Archiwum/2008/Katecheta-9-2008 (dostęp: 28.05.2021).

Chrostowski M., Edukacja religijna w Polsce: czas na zamianę?, „Łódzkie Studia Teologiczne" 29 (2020) 3, s. 39-52.

Chrostowski M., Schulpastoral für alle! Religionspädagogische und pastorale Impulse deutscher Schulpastoral für ein schulpastorales Modell in Polen (am Beispiel der Diözese Łomża), Berlin 2021 (w druku).

Czekalski R., Duszpasterstwo szkolne - czy wykorzystana szansa?, „Ateneum Kapłańskie” 3 (2004), s. 514-528.

de Lubac H., Die Tragödie des Humanismus ohne Gott. Feuerbach - Nietzsche - Comte und Dostojewskij als Prophet, Salzburg 1950.

Demmelhuber H., Schulpastoral in der Diözese Rottenburg-Stuttgart: Ein Dienst an und mit den Menschen im Lebensfeld Schule, w: Huch, was machen die denn da! Projekt Schulpastoral an Hauptschulen und Beruflichen Schulen 2000/2003, Dokumentation und Ergebnisse, red. Referat Schulpastoral Diözese Rottenburg-Stuttgart, Rottenburg-Stuttgart 2004, s. 6-10.

Diözese Augsburg, Christ sein in der Schule. Schulpastoral in der Diözese Augsburg, Augsburg 2006.

Erzbistum Hamburg, Positionspapier zur Verhältnisbestimmung von Katechese, Religionsunterricht und Schulpastoral in Hamburg. Empfehlungen zur Kooperation der katholischen Schulen und Pfarreien, Hamburg 2015.

Erzdiözese Freiburg, Verbindlicher Rahmen für die Schulpastoral in der Erzdiözese Freiburg, Freiburg i. Br. 2006.

Franciszek, „Evangelii Gaudium”: Adhortacja apostolska Evangelii gaudium o głoszeniu Ewangelii w dzisiejszym świecie, 24 listopada 2013, Kraków 2013.

Główny Urząd Statystyczny, Wyznania religijne w Polsce w latach 2015-2018, https:// stat.gov.pl/obszary-tematyczne/inne-opracowania/wyznania-religijne/wyznania-religijne-w-polsce-20152018,5,2.html (dostęp: 29.05.2021).

Görtz P., Ignatianische Schulpastoral. Anregungen für eine spirituelle Praxis an konfessionellen Schulen, Würzburg 2014. 
Humeniuk M., Paszenda I., Od redaktorek, w: Między ekskluzja a inkluzja w edukacji religijnej, red. M. Humeniuk, I. Paszenda, Wrocław 2017, s. 9-12.

Jówko E., Klimat społeczny w szkole inkluzyjnej, „Student Niepełnosprawny” 1 (2013), s. 43-59.

Katholisches Schulkommissariat in Bayern, RU-aktuell. Schulpastoral an Hauptschulen. Dokumentation und Ergebnisse des Erprobungsversuchs 1998/99-2001, München 2001.

Kienst M., Schulpastoral in der Erzdiözese Freiburg - Übersicht zu den Praxisfeldern, w: Schulkultur mitgestalten. Pastorale Anregungen und Modelle, red. J. Burkhard, P. Wehrle, Freiburg 2005, s. 35-38.

Kumher U., Schulpastoral und religiöse Pluralität. Ein Konzeptentwurf für die Auseinandersetzung mit religiöser Pluralität, Würzburg 2008.

Lames G., Schulseelsorge als soziales System. Ein Beitrag zur ihrer praktisch-theologischen Grundlegung, Stuttgart-Berlin-Köln 2000, s. 24-97.

Mariański J., Katolicyzm polski w procesie przemian, „Władza Sądzenia” 6 (2015), s. 29-45. Mendl H., Religionsdidaktik kompakt. Für Studium, Prüfung und Beruf, München 2011.

Mendl H., Schulpastoral. Schulpädagogische, theologische und religionspädagogische Rahmendaten, w: Schulpastoral konkret. Eine jugendverbandliche Perspektive, red. J. Martina, J. Kittel, Düsseldorf 2004, s. 8-34.

Mendl H., Schwarz Ch., Schulgottesdienst - Fakten, Einschätzungen, Perspektiven, „Kontakt. Informationen zum Religionsunterricht im Bistum Augsburg“ 1 (2000), s. $35-38$.

Pasamonik B., Moral panic about refugees in Poland as a manifestation of cultural transformation, „Multicultural studies” 1 (2017), s. 87-101.

Pew Research Center, Eastern and Western Europeans Differ on Importance of Religion, Views of Minorities and Key Social Issues, https://www.pewforum.org/ wp-content/uploads/sites/7/2018/10/Eastern-Western-Europe-FOR-WEB-1.pdf (dostęp: 10.01.2021).

Piela A., Łukjanowicz A., Islamophobia in Poland. National Report 2017, http://www.islamophobiaeurope.com/wp-content/uploads/2018/04/Poland.pdf (dostęp:14.02.2021).

Polak M., Pastoralna posługa Kościoła w szkole. Inspiracje dla polskiego duszpasterstwa, „Studia Pastoralne” 3 (2007), s. 275-293.

Rasińska A. Młodzi w Kościele, w: Kościół w Polsce. Raport, red. Katolicka Agencja Informacyjna, Warszawa 2021, s. 119-130.

Roth K., Inklusive Schulpastoral oder: was sich auch hinter dem schulpastoralen Prinzip der Gastfreundschaft verbergen kann, w: Handbuch Schulpastoral: für Studium und Praxis, red. w: A. Kaupp, G. Bussmann, B. Lob, B. Thalheimer, Freiburg 2015, s. 123-132.

Roth K., Sinnhorizonte christlich gestalteter Schule. Eine schulpädagogische Begründung der Schulpastoral an staatlichen Schulen, Hamburg 2013.

Schmitz S., Schulpastoral kontrovers, Ein kritischer Blick auf ungeklärte Verhältnisse zwischen Religionsunterricht, Schulseelsorge und Gemeindepastoral, Münster 2006. 
Seibt M., Schulpastoral an berufsbildenden Schulen des dualen Schulsystems: eine qualitativ-empirische Untersuchung zur Entwicklung von Qualitätskriterien für eine gelingende Schulpastoral an Berufsschulen, Berlin 2008.

Sekretariat der Deutschen Bischofskonferenz, Im Dialog mit den Menschen in der Schule. Eckpunkte zur Weiterentwicklung der Schulpastoral, Bonn 2020.

Sekretariat der Deutschen Bischofskonferenz, Schulpastoral - der Dienst der Kirche an den Menschen im Handlungsfeld Schule, Bonn 1996.

Skałbania B., Babiarz M., Edukacja właczająca jako przestrzeń dla rozwoju czy ryzyko wykluczenia i marginalizacji ucznia?, „Student Niepełnosprawny” 11 (2018), s. 17-27.

Sobór Watykański II, Konstytucji duszpasterska o Kościele w świecie współczesnym „Gaudium et spes”, 7. Grudnia 1965, Wrocław 2016.

Surzykiewicz J., Klimat a społeczna skuteczność szkoły, „Edukacja zdrowotna i promocja zdrowia w szkole" 12 (2007), s. 6-25.

Sztaba M., Pedagogika integracyjna wobec wieloaspektowego problemu samotności człowieka, „Rozprawy Społeczne” 8 (2013) 1, s. 52-60.

Verburg W., Abdel-Rahman A., Christliche Schulpastoral in Schulen mit religiös pluraler Schülerschaft, w: Handbuch Schulpastoral: für Studium und Praxis, red. A. Kaupp, G. Bussmann, B. Lob, B. Thalheimer, Freiburg 2015, s. 143-154.

Zuk A., Pastoralne zaangażowanie parafii w struktury szkolne: innowacyjny model wychowania społeczno-kulturowego, w: Człowiek - Środowisko życia - Edukacja, red. W. Theiss, Torun 2012, s. 228-262.

Żuk P., Żuk P., "Murderers of the unborn" and "sexual degenerates": analysis of the "anti-gender" discourse of the Catholic Church and the nationalist right in Poland, „Critical Discourse Studies” 17 (2020) 5, s. 566-588.

\section{Źródła internetowe}

http://www.edupedia.pl/words/index/show/285272_slownik_wyrazow_obcych-humanizowac.html (dostęp: 06.02.2021). 